The meeting was timed to coincide with the annual Comptoir Suisse at Lausanne, in order to give Swiss residents the advantage of return travel at single fare by means of an automatic ticket-stamping device inside the Comptoir, with a reduced entrance fee for members of the Society. The simultaneous disadvantage that hotels had to be booked long in advance kept away a certain number of members. Nevertheless, the sectional proceedings were on the whole as lively and well attended as ever, the Geophysical, Meteorological and Astronomical Section in particular being fortunate in having the director of the Swiss Meteorological Station, Prof. J. Lugeon, at hand in person after his extensive travels of recent years, partly in connexion with the International Geophysical Year and two of them to the North Pole, to report, with collaborators, on "Les Recoupements Radiogoniographiques des Grands Foyers Orageux de l'Hémisphere Nord depuis la Base Spitzberg-Suisse $(4100 \mathrm{~km}$.)" and "Comparaison des
Régimes des Parasites Atmosphériques Polaires et Européens", and to give a preliminary report on measurements of atmospheric electricity and radioactivity of the air at Murchison Bay during the International Geophysical Year. The History Section was specially interesting with reports on the mathematical aspect of the Hippocratic Logos (Dr. Lichtentaeler, of Leysin), on Baldasar Heseler's eyewitness account of Vesalius's first public anatomy lecture at Bologna in 1540 (Dr. N. Mani, of Basle) and on the little-known mathematician and philosopher de Crousaz, of Lausanne, 1663-1750 (Dr. Ed. Fueter, of Wädenswil, ZHH). Porhaps the Physics Section was the busiest, under the annual vice-president, Prof. D. Rivier, with twenty-eight papers mainly on metal, crystal and atomic physics.

Excursions after the meeting were organized for those interested in geology (3 days), mineralogy (2 days) and botany ( 2 days).

R. C. H. TANNeR

\title{
SCIENCE AND THE LIBRARY SERVICES IN BRITAIN
}

$\mathrm{T}$ HE programme of the annual conference of the Library Association usually includes two or three papers of some general scientific interest and, although that of the annual conference held at Torquay during September 22-25 was possibly of less scientific interest than usual, Prof. Lancelot Hogben's "Past, Present and Future of the Printed Page", Sir Sydney Roberts's "Reflections on the Roberts" Report", and Alderman F. J. Stott's "The Public Library as a Major Instrument of Education" are of wide interest. Besides this, Miss M. E. Wilden-Hart's "Observations on County and Municipal Practice" touched on various matters involved in the development of an adequate national library system whether for science and technology or in any other field. Earl Attlee's presidential address, succinct, wise and witty, illustrated the extent to which wide reading and the right handling of books are still positive constructive factors in modern life; and Lady Barlow discussed "Charles Darwin as Author".

Prof. Hogben addressed himself to three issues: Can other means of communication adequately replace the printed page ? Will their rightful exploitation diminish the demand for the printed page relative to the size of the literate public? And how far does a plan of peaceful co-existence for the two call for a now programme of book design? On the first, Prof. Hogben remarked that 'adequately' was the operative word, and the freedom to turn the pages backwards or forwards to interpret the author's meaning in the light of previous statements or of what occurred later was an incentive to concentrated attention and acted as a brake on superficial assent. To regard reliance on mechanized instruction without reliance on the printed page as calamitous did not mean that the more extensive use of sound or television should be regarded with disfavour or that such extension would curtail the need for book learning. On the contrary, Prof. Hogben thought that we would have to exploit new means of instruction and that radio sound and television could solve the modern problem of shortage of talented teachers in a world of wider educational opportunities if-.. and only if-we could give it a curricula orientation entirely divorced from the prepossessions of the entertainment business. The exploitation of the newest visual aids did not mean that there would be need for fewer books in the near future. In some of the backward territories there would be vastly more readers if we could use the new means to speed up universal literacy, and where literacy was already well-nigh universal the new means could so expand the appetite for learning as to stimulate powerfully the output of new informative literature.

As regards the third question, while there was no reason to anticipate that the exploitation of the new means at our disposal would diminish the demand for the printed page, and ample reasons existed for believing that it would increase that demand, we could certainly forecast that it would increasingly change the content of what printed matter is in demand and set a new standard of design for books which satisfy an abiding demand. Here Prof. Hogben referred to the possibilities opened up by gearing issued and printed material into editions which could subserve two educational objectives, sentences of one line in length permitting repetition of the same message line by line in several languages. In the new era the first challenge to intellectual effort was how most expeditiously we could make available to all persons everywhere the printed page; the second was how to make everywhere accessible to all, both one and the same printed page and one and the same human voice. The third great intellectual challenge was how to disperse over an ever-widening and deepening understanding less of the mechanical techniques at our disposal than of the peculiarly human innovations.

Sir Sydney Roberts began by pointing out that the central question his Committee had been asked to consider was what changes, if any, should be made in the administrative arrangements of the public library service, and this included possible transferences of responsibility from one type of library authority to another. Although there were obviously two clashing views of the functions of a public library, 
both were agreed that the public library service, by whatever type of authority it might be administered was essentially a feature of local government. Nevertheless, the Committee was clear that provision of library facilities should cease to be a local option and should become a statutory duty with ultimate authority vested in the Minister of Education. Librarianship, however, was a highly specialized function, and in Sir Sydney's view a committee responsible for a public library should be an independent committee reporting direct to the library authority. Directing attention to the Committee's comment that size and efficiency did not necessarily march together, and its view that full opportunity--at least three yearsshould be given to any non-county borough or urban district to demonstrate its ability to fulfil the required conditions before any change was made in its library status, Sir Sydney said that the Committee had had before it the proposals for the new National Lending Library for Science and Technology, and its consideration of such matters had confirmed its misgivings about the imperfections of the reference sections in many libraries. Co-operation between libraries of an entirely different character and constitution, however, could best be achieved by individual nogotiation, in the light of local conditions, between the libraries concerned. The main obstacle to higher efficiency in the working of the regional bureau, however, was finance, and the Committee was not prepared to advocate a standard pattern of administration over the whole country. Finally, after touching on the problems of book selection, financial and otherwise, Sir Sydney pointed out that the public libraries must take full account of the implications of the scientific revolution in which we live. They must stock both the technological text-books and reference books needed by their industrial and academic clients and they must make a judicious choice of those authors who attempt to explain the basic principles of scientific development to the non-scientific reader. They had also to recognize the sociological results of scientific discovery and development and meet adequately the recreational needs of leisure.

Alderman F. J. Stott, who began with a quotation from the report of President Eisenhower's Science
Advisory Committee, "Education for the Age of Science", stressing that the aim of an educational system must always be the development of the individual so that he could live the fullest life with himself and the community, elaborated further Sir Sydney Roberts's closing remarks. If the scientific age challenged technologists to make a special effort to ensure that their education was not detrimental to their balanced development as individuals and challenged non-technical people to keep in touch with the new language and thoughts of science, it was essential for our national welfare that we should stay in communication with each other, and the channels of communication could only be secured by the universal enjoyment of liberal education. Education, however, was being required to devote more and more of its resources to vocational and technical training at the expense of wider values, and while at work more and more were called upon to do less and less thinking, in our ever-increasing leisure more and more were content to leave the planning of their leisure to the instruments of mass entertain. ment.

In this situation, in which the integrity and full flowering of the individual were threatened on all three counts, Alderman Stott thought that the public library had an important part to play. A survey of readers recently made in the Plymouth public libraries indicated that, whereas in Plymouth $\mathbf{3 3 , 0 0 0}$ scholars at primary, secondary and grammar schools spend 33.5 million hours in attendance, 66,000 readers of all ages devoted 36.5 million leisure hours to reading, of which 15 million were devoted to reading of a deliberately self-chosen, informative and educa. tional character. On the provision of this service some $£ 80,000$ a year was spent, compared with about $£ 2$ million on formal education in primary and secondary schools, but Alderman Stott, of course, emphasized that on two-thirds to three-quarters of the population the public library services made no impact at all. He did not think it was simply a matter of increasing the provision for public library services but rather, as Lord Attlee had suggested, for encouraging children early in life to use and cherish books. There was also need for much more publicity and some attempt to meet the needs of individuals.

\section{INDUSTRY AND HEALTH IN BRITAIN}

$\mathrm{T}$ HE annual report of the Chief Inspector of Factories for the year 1958 follows the new form adopted last year, which was very well received and there is again a separate report on industrial health (Ministry of Labour and National Service. Pp. 95. (Cmnd. 810.) London: H.M. Stationery Office, 1959. 5s. 6d. net). While the number of reported accidents fell by 4 per cent, from 174,713 to 167,697 , and was the lowest reported for any year since 1935, fatal accidents rose from 651 to 665 . For factories alone the figure declined by 5 per cent to 143,099 , of which 368 were fatal ; but in building operations and works of engineering construction there were increases from 14,568 to 15,017 and from 1,924 to 2,329 , respectively. The former included a considerakle increase in fatalities due to falls, especially of materials, and this appears to be due to much demolition work being carried out by inexperienced personnel with little or no appreciation of the loading and stresses in various parts of the structure on which they are working. No figures are available for accident incidence rates of individual industries, although the report gives comparative frequency rates, based on voluntary returns from individual firms, and it is hoped to publish a table of incidence rates in next year's report. The distribution of accidents between the sexes and between young persons and adults was little changed, but the report points out that, in spite of the emphasis placed on training young persons entering industry, 9,838 young persons were involved in notifiable accidents and 8 of them were killed: in some industries it is still 